\title{
Effects of Varying Grilled Sorghum Content on the Quality Parameters of Urwagwa, a Traditional Rwandese Banana-based Alcoholic Beverage
}

\author{
Emmanuel Munezero ${ }^{1}$, Samuel Imathiu ${ }^{2} \&$ Munyanganizi Bikoro ${ }^{3}$ \\ ${ }^{1}$ Institute for Basic Sciences, Technology and Innovation, Pan African University, P. O. Box 62000, Nairobi, \\ Kenya \\ ${ }^{2}$ Department of Food Science and Technology, Jomo Kenyatta University of Agriculture and Technology, P. O. \\ Box 62000, Nairobi, Kenya \\ ${ }^{3}$ University Centre of Research and Professionalization (CURP), Catholic Institute of Kabgayi, P.O. Box 62 \\ Gitarama, Rwanda \\ Correspondence: Emmanuel Munezero, Institute for Basic Sciences, Technology and Innovation, Pan African \\ University, P.O. Box 62000, Nairobi, Kenya. Tel: 254-796-217-344. E-mail: \\ munezeroemmanuel.me@gmail.com
}

Received: August 1, 2018 Accepted: August 17, $2018 \quad$ Online Published: October 17, 2018

doi:10.5539/jfr.v7n6p70 URL: https://doi.org/10.5539/jfr.v7n6p70

\begin{abstract}
An alcoholic beverage called Urwagwa is a common and popular traditional Rwandese drink that is produced from banana juice supplemented with coarsely ground grilled sorghum. Due to limited information on how different sorghum concentration affected the physico-chemical characteristics of this traditional beverage, a study was carried out to investigate how varying this ingredient influenced the quality of the final product. Different levels of grilled coarsely ground sorghum $(0 \%, 2 \%, 5 \%, 7 \%, 10 \%$ and $15 \%)$ were mixed with banana juice and natural fermentation allowed to take place in six separate fermenters for six days at room temperature $\left(25^{\circ} \mathrm{C}\right)$. Four parameters; ethanol content, total soluble solids, $\mathrm{pH}$ and titratable acidity were monitored after every 24 hours for 144 hours. Results obtained at the end of fermentation indicated that the ethanol content in all fermenters ranged from $10-12 \% \mathrm{v} / \mathrm{v}$, total soluble solids $8.1-9.7^{\circ} \mathrm{Brix}, \mathrm{pH} 4.0-4.7$ and titratable acidity $0.6-0.9 \%$. The highest fermentation rate was observed in fermenters containing ground grilled sorghum compared to the control (0\% sorghum added).The highest total soluble solid at the completion of fermentation was found in banana beverage with zero percent of sorghum while the highest $\mathrm{pH}$ was generally found in fermenters with sorghum combinations. High titratable acidity was observed in fermenter with zero percent of sorghum. The concentration of 5\% of ground grilled sorghum was found to result to the most desirable alcoholic banana beverage as it gave the highest yield of ethanol content and other biochemical parameters, as well as a more desirable flavor. Based on these findings, it could be recommended that the traditional Urwagwa brewers adopt the $5 \%$ of sorghum content in the production process in order to obtain a better quality and more acceptable alcoholic beverage.
\end{abstract}

Keywords: alcoholic drinks, banana, banana beverage, traditional alcoholic beverage, urwagwa

\section{Introduction}

Alcoholic beverages are among the leading drinks in many African communities in terms of consumption (Shale, Mukamugema, Lues, \& Venter, 2014). Due to their high consumption levels, these beverages have vitalized both traditional and industrial production. Almost all African societies have well established domestic production industries for the fermented alcoholic beverages, which to a great extent depends on traditional techniques, processes and resources (Mohapatra, Mishra, \& Sutar, 2010). Commercial production is of a larger scale, adopting an industrial outlook that is often oriented towards mass production for consequent economic value. Despite the lower production levels of traditionally produced alcoholic beverages compared to commercially produced ones, their outlook and preference for consumption, especially by low-income earners and rural folks is on an upward trajectory in developing countries, Rwanda included. The reasons for this preference are possibly due to their low prices and the strong connection they have with the traditional cultures. 
In Rwanda, Urwagwa, a popular traditional banana-based beverage, has a long historical significance to the consuming communities. This alcoholic beverage, which is made from banana juice blended with ground grilled sorghum through spontaneous fermentation, is mainly confined to domestic production with annual production of 700 million litres and an average consumption per capita of about 1.2 litres per day (Immaculate Kanyana, 2013). Although this alcoholic beverage can be made using a wide variety of ripe bananas cultivars (AAA-EAHB), the most commonly used for its production in Rwanda are forty cultivars belonging to Lujugira-Mutika subgroup, with 'Intuntu', 'Intokatoke', 'Injagi, 'Mbwaziruma, Gisubi (ABB), Gros Michel (AAA) and 'Kamaramasenge being the most preferred (Karamura, Karamura, \& Tinzaara, 2012). During its production, sorghum which is thought to accelerate the fermentation process and enhance flavour development in the end product is included as part of the composite mixture (Wilson, 2012; Munyanganizi, 1975).

The Urwagwa production process is however yet to be determined and documented through scientific studies (Wilson,2012). Although traditional banana-based alcoholic beverage production is an expansive domestic industry and has a long historical existence in Rwandan society, there is little research conducted on its production. The limited studies carried out on the fermentation of banana to produce alcoholic beverages have rarely investigated the aspect of sorghum involved in the fermentation process and the physico-chemical changes that normally take place during production (Wilson, 2012). It is for this reason that this study was carried out to investigate the effects of varying sorghum concentration on selected physico-chemical parameters that can have an influence on the final product quality. The study also served to identify the optimum banana juice-sorghum combination that would result to the best quality alcoholic beverage under the prevailing production conditions.

\section{Materials and Methods}

\subsection{Collection and Ripening of Banana for Urwagwa Production}

Four physiologically mature banana cultivars of Kayinja (Musa genus), Indaya, Intuntu or Igikashi musa groups (AA, AB, AAA, AAB, ABB) and Poyo musa robusta (AAA group) in which Intuntu represented 67 percent and 33 percent of rest respectively were collected from a local market around Rugende in Gasabo district of Rwanda and transported in plastic crates under normal conditions to Centre de Formations et des Recherches pour le Développement des Technologies Appropriées (CFRDTA) for experimentation. The bananas were placed in plastic container and covered by spear grass (Imperata cylindirica) and green banana leaves in order to ensure the warm conditions and promote ethylene production and accumulation necessary for ripening. The bananas took 6 days to ripen indicated by their change in peel colour to yellow and softening.

\subsection{Banana Juice Extraction}

Ripe bananas were peeled manually by hand peeling. Juice extraction was mechanically made by mixing $69 \mathrm{~kg}$ of peeled banana with $6.9 \mathrm{~kg}$ of special grass (Imperata cylindirica) which had been previously washed and dried in order to remove dust and other miscellaneous materials that could contaminate the beverage. The banana juice extraction, which was aided by Imperata cylindirica, was achieved by use of a fabricated juice extracting machine. The juice was filtered using a plastic sieve and the remaining juice in banana-grass pulp was exhausted by pressing using a fabricated juice extracting machine pressor.

\subsection{Banana Juice-Sorghum Combinations Used in Urwagwa Production}

The obtained banana juice after pulp squeezing was pasteurized at $90^{\circ} \mathrm{C}$ for 30 minutes to prevent premature fermentation caused by indigenous yeast and lactic acid bacteria and other contaminating microorganisms. Lightly roasted sorghum, often red sorghum in ground form is commonly used in the production of banana beer in Rwanda as an adjunct where it is thought to contribute to the flavour and colour of the finished product (Munyanganizi,1975; Wilson, 2012). Different proportions of sorghum were mixed with a constant amount of extracted banana juice as shown in Table 1 . The red sorghum used in this study which was previously washed, dried, lightly roasted and ground for urwagwa production was bought from Kimironko market in Rwanda.

Table1. Banana juice-sorghum combinations used in the production of Urwagwa through spontaneous fermentation

\begin{tabular}{ll}
\hline Banana juice (1) & Sorghum $(\% \mathrm{w} / \mathrm{v})$ \\
\hline 3 & 0 \\
3 & 2 \\
3 & 5 \\
3 & 7 \\
3 & 10 \\
3 & 15 \\
\hline
\end{tabular}




\subsection{Determination of Initial pH of Banana Juice and Banana Juice-Sorghum Mixture}

The $\mathrm{pH}$ of banana juice and banana juice-sorghum composite mixture before fermentation was evaluated with $\mathrm{pH}$ meter (PB-11Sortorius, Germany) at $25^{\circ} \mathrm{C}$. A volume of $20 \mathrm{ml}$ was taken and the measurement of each sample was done after calibration of pH-meter with a buffer (4-7).

\subsection{Determination of Protein Content in Banana Juice-Sorghum Mixture before Fermentation}

The protein content of banana juice-sorghum mixture was determined on the basis of total nitrogen content by using auto titration Kjeltec models 2300 (Denmark). A representative sample of $0.4 \mathrm{~g}$ of each of the composite mixture was weighted into $100 \mathrm{ml}$ labelled digestion tubes by use of an electronic balance (Sortorius CPA3245). One Kjeltabs $\mathrm{Cu} 3.5$ tablet of catalyst and $6 \mathrm{ml}$ of concentrated $\mathrm{H}_{2} \mathrm{SO}_{4}$ were added to each digestion tube. The samples were heated at $420^{\circ} \mathrm{C}$ for 2 hours and after digestion, they were cooled to room temperature $\left(25^{\circ} \mathrm{C}\right)$. After cooling the tubes containing the samples were transferred into distillation unit (Foss $2300 \mathrm{Kjeltec}$ ) and protein percentage determined according to the Kjeltec machine manufacturer's instructions where mass of each sample was entered in the Kjeltec system and the protein was reported as percentage and calculated according to the formula by (Muriro,2017). On the basis of early determinations, the average nitrogen $(\mathrm{N})$ content of proteins was found to be about 16 percent, which led to use of the calculation $\mathrm{N} \times 6.25(1 / 0.16=6.25)$ to convert nitrogen content into protein content. The following equation was used in the calculation of protein content in the samples.

$$
\begin{gathered}
\% \text { Nitrogen }=\frac{(T-B) * N * 14.007 * 100}{W(m g)} \\
\% \text { Protein }=\% \text { Nitrogen } * F
\end{gathered}
$$

Where;

$\mathrm{T}=$ Titration volume for sample $(\mathrm{ml})$

$\mathrm{B}=$ Titration volume for blank $(\mathrm{ml})$

$\mathrm{F}=$ Conversion factor for nitrogen to protein

$\mathrm{W}=$ Weight of the sample $(\mathrm{mg})$

\subsection{Determination of Total Soluble Solids (TSS) in Banana Juice-Sorghum Mixture before Fermentation}

Total soluble solids of the banana juice and banana juice-sorghum were determined as ${ }^{\circ}$ Brix according to Serpen, (2012) with some modification by which hand held optical refractometer was replaced by A.Kruss Optronic refractometer GmbDR6100 (Germany) which give a direct reading of ${ }^{\circ} \mathrm{Brix}$, or relative sugar concentration. The refractometer was cleaned using distilled water before sample analysis. Distilled water was used as control in this experiment $\left(0^{\circ} \mathrm{Brix}\right)$. The amount of sugar in the sample was directly read from the refractometer.

\subsection{Fermentation of Banana Juice and Banana Juice-Sorghum Mixtures}

The fermentation was carried out in six fermenters of 3 litres of volume. One fermenter, with no added sorghum (banana juice only) served as the control. The experiment was carried out in triplicates. The content in fermenters was left to ferment spontaneously at room temperature $\left(25^{\circ} \mathrm{C}\right)$ for 6 days. The whole production process, from ripening of the bananas to final fermented alcoholic product took 13 days.

\subsubsection{Monitoring of the Fermentation Process}

During fermentation $100 \mathrm{ml}$ of samples was collected, in sterile bottles from each fermenter after every 24 hours for 6 days to determine various physico-chemical parameters $(\mathrm{pH}$, titratable acidity, ethanol accumulation and sugar). After collection the samples were pasteurized at $60^{\circ} \mathrm{C}$ for 15 minutes to end fermentation after which they were stored at $4^{\circ} \mathrm{C}$ in the refrigerator before analysis.

\subsubsection{Determination Ethanol Content}

Test for ethanol content was conducted using WineScan ${ }^{\mathrm{TM}} \mathrm{SO} 2$ (Denmark) from the beginning to the end of the fermentation process. A $100 \mathrm{ml}$ of sample to be analysed was filtered by using Whatman filters of $11 \mu \mathrm{m}$ size and $20 \mathrm{ml}$ of filtrate transferred into vials from where they were sucked by the column of WineScan ${ }^{\mathrm{TM}} \mathrm{SO} 2$ for analysis. Before analysing each sample, there was auto-cleaning of WineScan ${ }^{\mathrm{TM}} \mathrm{SO} 2$ through zero setting the machine according to the manufacturer's instructions.

\subsubsection{Determination of Total Soluble Solids (TSS)}

Total soluble solids of urwagwa were determined as described for banana juice-sorghum composite mixture 
above.

\subsubsection{Determination of $p H$}

The $\mathrm{pH}$ of the whole fermentation process was evaluated as aforementioned for banana juice and banana juice-sorghum combination before fermentation.

\subsubsection{Determination of Titratable Acidity}

The titratable acidity, expressed in percent of lactic acid, was determined by the titrimetric method according to (Association of Official Analytical Chemist[AOAC], 2005). A 5ml subsample from the $100 \mathrm{ml}$ sample was used for titration after decarbonating by shaking. The sample was diluted twice with distilled water $(10 \mathrm{ml})$ which was previously brought to boil at $90^{\circ} \mathrm{C}$ and cooled at room temperature $\left(25^{\circ} \mathrm{C}\right)$. Three drops of $1 \%$ phenolphthalein indicator was added to the sample in a conical flask and titrated with $0.0909 \mathrm{M} \mathrm{NaOH}$ to a persistent faint pink colour compared against a white background. The titre volume was noted and used for calculations of the amount of total titratable acidity as percentage of lactic acid using the equation below.

$$
\% \text { lactic acid }=\frac{\text { ml of } 0.0909 \mathrm{M} \mathrm{NAOH} * \text { Normality of } \mathrm{NAOH} * \mathrm{MW} \text { of acid }}{\text { Volume of sample } * 10}
$$

Where MW $=$ molecular weight

\section{Results and Discussion}

\subsection{Banana Juice and Banana Juice-Sorghum Composition in Regard to Soluble Sugar Concentration, Protein Content and $\mathrm{pH}$ before Fermentation}

The addition of grilled sorghum to banana juice marginally increased the $\mathrm{pH}$, soluble sugar concentration and protein content of the composite mixtures, and this change tended to increase with the percentage increase in grilled sorghum added (Table 2). Out of the three parameters determined, more change was noticeable with protein concentration than with the changes in $\mathrm{pH}$ and soluble sugar concentration on addition of grilled sorghum. The $\mathrm{pH}$ ranged from $4.68 \pm 0.05$ to $4.75 \pm 0.03$ ( $0 \%$ sorghum added and $15 \%$ sorghum added respectively), soluble sugar concentration ranged from $21.00 \pm 0.07$ to $21.37 \pm 0.17(0 \%$ sorghum added and $15 \%$ sorghum added respectively) and protein content $1.0 \pm 0.08$ to $2.7 \pm 0.20$ (0\% sorghum added and $15 \%$ sorghum added respectively). Total soluble solids and protein are the main nutrients required for growth of yeast in wort fermentation. The slight increase in total soluble solids as well as protein concentration on addition of varying quantities of grilled sorghum can be attributed to the presence of free sugars and protein found in sorghum.

Table 2. Banana juice and banana juice-sorghum composition in regard to $\mathrm{pH}$, soluble sugar concentration and protein content before fermentation. Values are means of triplicate determinations $\pm \mathrm{SD}$

\begin{tabular}{llll}
\hline Sorghum concentration & $\mathrm{pH}$ & Sugar $\left({ }^{\circ}\right.$ Brix $)$ & Protein $(\mathrm{g})$ \\
\hline $0 \%$ & $4.68 \pm 0.05$ & $21.00 \pm 0.07$ & $1.0 \pm 0.08$ \\
$2 \%$ & $4.69 \pm 0.02$ & $21.07 \pm 0.06$ & $1.3 \pm 0.01$ \\
$5 \%$ & $4.70 \pm 0.01$ & $21.09 \pm 0.02$ & $1.6 \pm 0.01$ \\
$7 \%$ & $4.71 \pm 0.06$ & $21.10 \pm 0.10$ & $1.8 \pm 0.09$ \\
$10 \%$ & $4.73 \pm 0.04$ & $21.23 \pm 0.12$ & $2.1 \pm 0.14$ \\
$15 \%$ & $4.75 \pm 0.03$ & $21.37 \pm 0.17$ & $2.7 \pm 0.20$ \\
\hline
\end{tabular}

\subsection{Effect of Sorghum Content on Ethanol Concentration}

Generally, the onset of ethanol production started at the same time in all the six fermenters (including the control), with even quantifiable levels at the start of the experiment (Figure 1). It was observed that the production of ethanol for all the composites tended to increase with time as well as the increase in percentage of sorghum added to the banana juice. The trend for the production of ethanol for all the composites except the one containing no sorghum (control) followed a similar pattern. There was a sharp increase in ethanol production for all the composites after the $48^{\text {th }}$ hour except for the one containing no sorghum where the increase in this parameter seemed to occur rather steadily up to the $72^{\text {nd }}$ hour, after which there was a sharp increase. Except for the control and the composite containing 10\% sorghum, in all the other combinations, ethanol production tended to start decreasing before or at the start of the $144^{\text {th }}$ hour of fermentation with the composite containing $15 \%$ sorghum showing the earliest onset of ethanol production decline. The final ethanol content in all fermenters ranged from (10.3-12.2\%) with the control resulting in the least concentration and the composite containing $10 \%$ sorghum resulting into the highest concentration (Figure 1). 


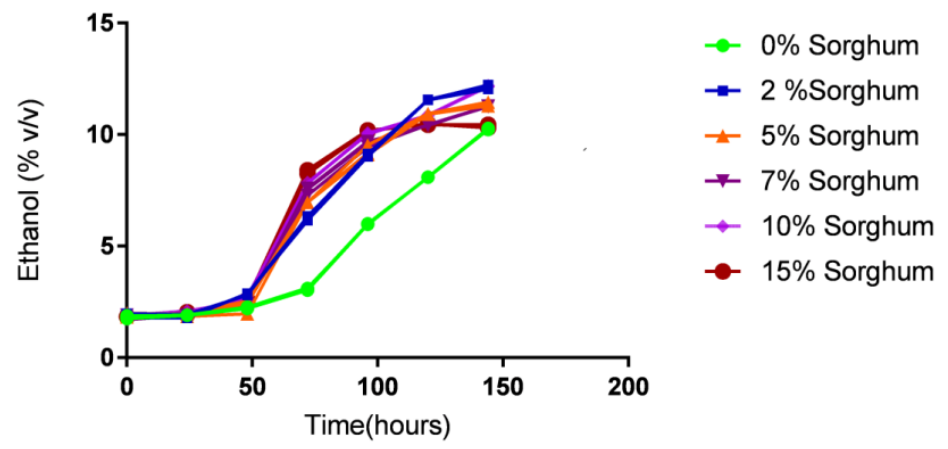

Figure 1. Changes in ethanol concentration during the spontaneous fermentation of urwagwa with varying sorghum combinations

These results showed that the alcohol content does not only result from banana juice but also from added roasted sorghum. The initial concentration of soluble sugars in banana juice with no added sorghum was the least at $21^{\circ}$ Brix (Table 2). It is therefore not a surprise that the control (banana juice with no added sorghum) yielded the least ethanol than the fermenters containing the composite mixtures. Sugars are normally converted to ethanol by yeasts during fermentation, and the higher the concentration, the higher the expected ethanol yield (Raikar, 2012). From limited data available, previous studies by Davies (1993) and Shale et al.(2013) showed that banana beer with an ethanol content of $11-15 \%(\mathrm{v} / \mathrm{v})$ and $8.7-18.1 \%(\mathrm{v} / \mathrm{v})$ was produced from undiluted banana juice and from indigenous banana beer respectively. Similar study done by Byarugaba-Bazirake (2013) and Dieu et al. (2017) reported an alcohol content of 6.4-14.6\% ( v/v) from banana beverage made from three banana cultivars and $12 \%(\mathrm{v} / \mathrm{v})$ ethanol in Rwanda banana beverage respectively.

There was early decline of ethanol in fermenter with $15 \%$ of sorghum and according to (Ferreira, 2004) the acetic acid bacteria may be responsible for oxidation of ethanol to acetic acid, leading to its reduction. The high trend of ethanol production in all fermenters other than the control could be attributed to the presence of nitrogen and minerals from sorghum that could have favoured the conditions for yeast growth compared to the fermentation of banana juice with no sorghum added (Deesuth, Laopaiboon, Jaisil, \& Laopaiboon, 2012). Similar study by Picki-reix et al.(1986) has established the clear relationship between the ethanol production with free amino acids concentration in wort by which high free amino acid corresponded with high ethanol production. According to Carrau et al. (2008), Picki-reix et al. (1986), Barrajón-Simancas et al.(2011), Jiranek et al. (1993) and Sablayrolles et al. (1996) nitrogen deficiency in wort may lead to the sluggish of fermentation, the problem of which could be solved by supplementation with a nitrogen source. The need for a source of nitrogen in fermentation is also highlighted by (Deesuth et al.,2012; Akunna,2015). Sorghum is known to be a good source of nitrogen as well as other essential nutrients including minerals such as potassium that are reported to be necessary for yeast growth according to(Lindsay, 2010). (Kudo, Vagnoli, \& Bisson, 1998) have reported the significance played by potassium in early fermentation of wort through acceleration of glucose consumption by yeast. In addition, potassium which is found in high concentration in sorghum plays a key role in $\mathrm{pH}$ tolerance of Saccharomyces and high yield of ethanol is produced at pH of 4.5 (Asli, 2010). Potassium deficiency may lead to the reduction of fermentation capacity of individual yeast cells or fermentation capacity of culture through the loss of yeast cell viability (Ferreira, 2004).

\subsection{Effect of Sorghum Concentration on Soluble Sugar during Fermentation}

Sugar is one of the main substrate in alcoholic fermentation of the wort. The initial concentration of total soluble sugars in all the combinations, at time zero, including in the control was on average, $21^{\circ}$ Brix. This remained largely unchanged for all the combinations up to the $48^{\text {th }}$ hour of the fermentation except for the sample containing $15 \%$ sorghum which showed a slight reduction $\left(20^{\circ}\right.$ Brix $)$. There was a sharp decline in soluble sugar concentration after the $48^{\text {th }}$ hour of fermentation for all combinations except with the control where the decrease was observed to be steady (Figure 2). 


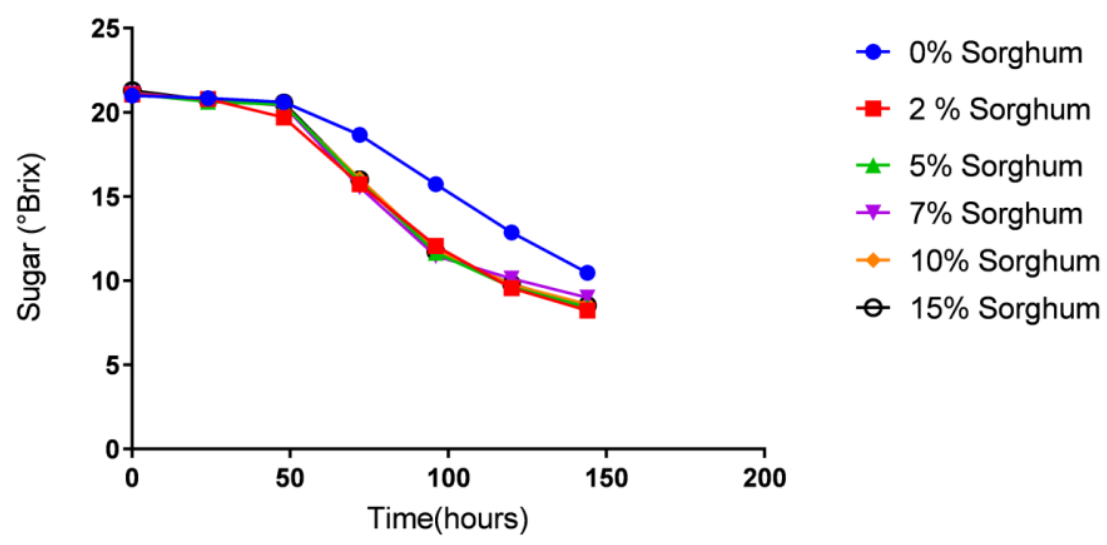

Figure 2. Changes in soluble sugar concentration ( ${ }^{\circ}$ Brix) during fermentation of urwagwa with varying sorghum concentration

At the end of the fermentation ( $144^{\text {th }}$ hour), all the samples seemed to have similar levels of soluble sugars remaining. Previous studies indicates that the main fermentable sugars in ripe bananas are glucose (19-22\% of total sugar), fructose (12-17\% of total sugar) and sucrose (62-68\% of total sugar) (Hammond, Egg, Diggins, \& Coble, 1996). According to (Hammond et al.,1996) the ideal sugar content of unfermented wort and which lead to the production of beverage of $8-12 \%(\mathrm{v} / \mathrm{v})$ ethanol should be around $15-25 \%(\mathrm{w} / \mathrm{w})$. This observation is in agreement with the findings of this study in terms of soluble sugar concentration and ethanol produced during fermentation as previously discussed. Similar findings have also been reported (Byarugaba-Bazirake, 2013). The sugar level at the end of fermentation was slightly higher in fermenter with zero percent of sorghum $\left(9.7^{\circ}\right.$ Brix $)$ which is attributable to high residual sugar.

\subsection{Effect of Sorghum Concentration on $\mathrm{pH}$ Variation during Fermentation}

The $\mathrm{pH}$ level is an essential component of the fermentation process as it can have an impact on the quality of the fermenting process as well as outcome of the final product following the process. The initial $\mathrm{pH}$ of all the samples, including the control was similar, ranging from 4.0-4.7. From a previous study of Munyanganizi (1974) and (Newilah, Tomekpe, Fokou, \& Etoa, 2009), the pH of fully ripened bananas ranges from 4.2 to 4.9, a finding which is in agreement with the results of this study. There was a common trend for all the samples during the fermentation process; the $\mathrm{pH}$ decreased as the fermentation progressed (Figure 3).

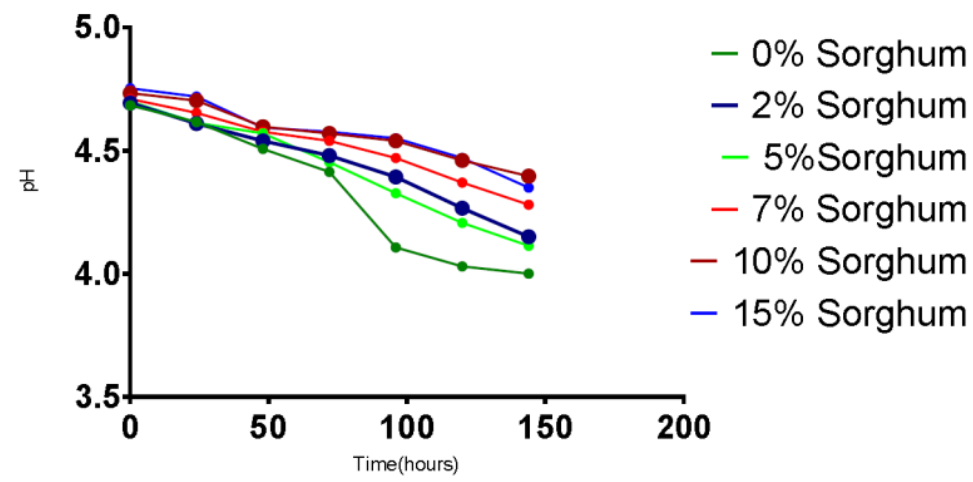

Figure 3. Changes in $\mathrm{pH}$ during fermentation of urwagwa with varying sorghum concentration

With the exception of the control (no sorghum added), the $\mathrm{pH}$ of the rest of the samples were found to decrease steadily up to the end of the fermentation period. There was a sharp decrease of $\mathrm{pH}$ in the control sample between the $72^{\text {nd }}$ and $96^{\text {th }}$ hour of fermentation. The less sharp drop in $\mathrm{pH}$ in samples containing sorghum compared to the control could be explained by higher content of minerals in sorghum that may have led to high buffering of the wort (Munyanganizi,1976). According to (Rwanda Standard Board,2017), the pH of banana beverages should range from 4.0 to 5.0 which means that the final products of this study complies with the country's requirement in terms of this attribute. 


\subsection{Effect of Sorghum Concentration on Titratable Acidity}

Titratable acidity reflects the number of protons recovered during titration of acid by strong base at specific end point and it is an approximation of total acidity in a given product (Boulton, 1980). All the samples prior to the fermentation process (time zero) had quantifiable acidity which averaged to 0.17 . There was a noticeably exponential increase in titratable acidity for all the samples between time zero and 24 hours during fermentation, after which the increase, for all the samples became gradual (Figure 3).

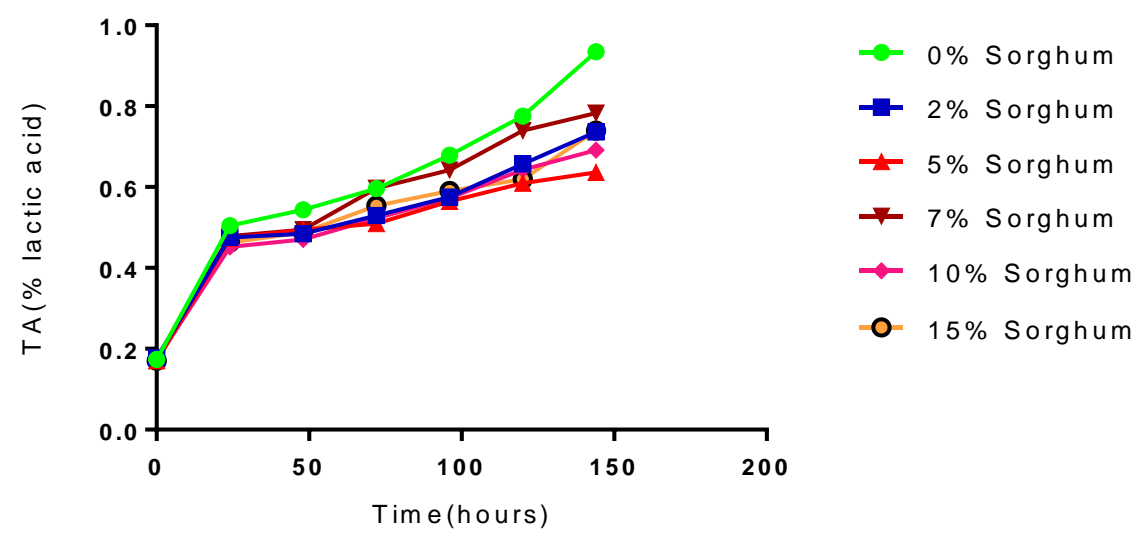

Figure 4. Changes in titratable acidity during fermentation of Urwagwa with varying sorghum concentration

Generally, a similar trend for all the samples in the development of the acidity (increase) was observed throughout the fermentation period. The acidity in the final products ranged from 0.64 and 0.93 . The highest titratable acidity was found in banana juice fermented without sorghum compared to those with added sorghum. High titratable acidity in sample containing zero percent sorghum may be attributed to the possibility of presence of lactic bacteria involved in early fermentation compared to samples with sorghum added as at this point the fermenters with sorghum added had high ethanol content that could reduce the population of lactic acid bacteria (Sigmon, 1993). According to (Wilson et al.,2012), titratable acidity in traditional alcoholic banana beverage ranges from 0.18 to $0.9 \%$ while (Akubor, Obio, Nwadomere, \& Obiomah, 2003) found $0.85 \%$ in final banana alcoholic beverage. Byarugaba-Bazirake,(2013) also reported titratable acidity expressed as g/L in banana alcoholic beverage produced by conventional and modern techniques from different banana cultivars which ranged from 5.24 to 8.4 , which is in agreement with obtained results of this study.

\section{Conclusion}

Addition of lightly grilled sorghum in banana juice during the production of Urwagwa was found to be a good adjunct in fermentation due to its positive influence on the quality parameters assessed. Physico-chemical parameters investigated in this study by using different sorghum concentration were found to display a positive aspect in fermentation which, for example resulted to the sharp ethanol production. It was observed that the production of ethanol for all the composites tended to increase with time as well as the increase in percentage of sorghum added to the banana juice while $\mathrm{pH}$ and sugar seemed to decrease steadily up to the end of the fermentation period. Total titratable acidity as one of quality requirements for banana based alcoholic parameter was found generally to be similar in all samples at the completion of fermentation compared to the control. Addition of 5\% grilled sorghum was found to be the optimal concentration leading to the best alcoholic beverage quality parameters in terms of ethanol content, $\mathrm{pH}$ and total titratable acidity which are in accordance with banana based alcoholic requirements. Economically, there is a big interest to use the minimum possible quantity of sorghum which fits with the highest quality of beverage meeting the standards for Urwagwa.

\section{Acknowledgment}

The author would like to thank African Union for financially supporting this work through Pan African University, Institute for Basic science, Technology and Innovation. Great gratitude also is conveyed to Rwanda Standard Board for their contributions to the achievement of this study through use their research facilities.

\section{References}

Akubor, P. I., Obio, S. O., Nwadomere, K. A., \& Obiomah, E. (2003). Production and Quality Evaluation of Banana Wine, Plant Foods for Human Nutrition, 58(3), 1-6 
Akunna, J. C. (2015). Brewing Microbiology. Brewing Microbiology. https://doi.org/10.1016/B978-1-78242-331-7.00019-8

Asli, M. S. (2010). A study on some efficient parameters in batch fermentation of ethanol using Saccharomyces cerevesiae SC1 extracted from fermented siahe sardasht pomace. African Journal of Biotechnology, 9(20), 2906-2912. https://doi.org/10.4314/ajb.v9i20.

Association of Official Analytical Chemist. (2005). Official Methods of Analysis of AOAC International (18th ed., Vol. 18th Editi). Gaithersburg, Md. : AOAC International, 2005.

B.Munyanganizi, C. (1976). Etude Comparative de deux procédés d'extraction du jus de banane appliqués ā deux Variétés différentes. Industries Alimentaires et Agricoles.

Barrajón-Simancas, N., Giese, E., Arévalo-Villena, M., Úbeda, J., \& Briones, A. (2011). Amino acid uptake by wild and commercial yeasts in single fermentations and co-fermentations. Food Chemistry, 127(2), 441-446. https://doi.org/10.1016/j.foodchem.2010.12.151

Boulton, R. (1980). The Relationships between Total Acidity, Titratable Acidity and pH in Wine. Vitis, 19(1), 113-120. Retrieved from http://www.vitis-vea.de/admin/volltext/e017796.pdf

Byarugaba-Bazirake, G. W. P. van R., \& W. K. (2013). The influence of commercial enzymes on wine clarification and on the sensory characteristics of wines made from three bana. American Journal of Biotechnology and Molecular Sciences. Institute of Wine Biotechnology, University of Stellenbosch, South Africa. 41-62. https://doi.org/10.5251/ajbms.2013.3.2.41.62

Carrau, F. M., Medina, K., Farina, L., Boido, E., Henschke, P. A., \& Dellacassa, E. (2008). Production of fermentation aroma compounds by Saccharomyces cerevisiae wine yeasts : e $;$ ects of yeast assimilable nitrogen on two model strains, 8, 1196-1207. https://doi.org/10.1111/j.1567-1364.2008.00412.x

Davies, G. (1993). Domestic Banana-Beer Production in Mpigi District, Uganda. The International Magazine on Banana and Plantain, 2(1), 12-15.

Deesuth, O., Laopaiboon, P., Jaisil, P., \& Laopaiboon, L. (2012). Optimization of nitrogen and metal ions supplementation for very high gravity bioethanol fermentation from sweet sorghum juice using an orthogonal array design. Energies, 5(9), 3178-3197. https://doi.org/10.3390/en5093178

Dieu, H. J. De, Kubana, I., Claudine, M., Claire, I., Eric, K., Labs, T., ... Africa, S. (2017). Comparative Study of Physicochemical and Bacteriological Characteristics of Banana Wines Produced by Conventional and Modern Techniques in Southern province of Rwanda, 5(5), 192-198. https://doi.org/10.12691/ajfst-5-5-4

Ferreira, J. (2004). Factors influencing the fermentation performance of commercial wine yeasts by.

Hammond, J. B., Egg, R., Diggins, D., \& Coble, C. G. (1996). Alcohol from bananas. Bioresource Technology, 56(1), 125-130. https://doi.org/10.1016/0960-8524(95)00177-8

Kanyana, I., Ouma, E., \& Van Asten, P. (2013). Quality assesment of banana juice and beer in Rwanda. Journal of Food Technology.

Shale, K., Mukamugema, J., Lues, R. J., Venter, P., \& Mokoena, K. K. (2013). Characterisation of selected volatile organic compounds in Rwandan indigenous beer 'Urwagwa' by dynamic headspace gas chromatography-mass spectrometry. African Journal of Biotechnology, 12(20), 2990-2996. https://doi.org/10.5897/AJB12.1173

Karamura, D. A., Karamura, E., \& Tinzaara, W. (2012). Banana cultivar Names,Synonyms and their Usage in East Africa.

Kudo, M., Vagnoli, P., \& Bisson, L. F. (1998). Imbalance of pH and potassium concentration as a cause of stuck fermentations. American Journal of Enology and Viticulture, 49(3), 295-301.

Lindsay, J. (2010). Sorghum: An Ancient, Healthy and Nutritious Old World Cereal, 1-28. Retrieved from http://digitalcommons.unl.edu/intsormilpubs\%5Cnhttp://digitalcommons.unl.edu/intsormilpubs/7

Mohapatra, D., Mishra, S., \& Sutar, N. (2010). Banana and its by-product utilisation: An overview. Journal of Scientific and Industrial Research, 69(5), 323-329.

Munyanganizi, B. (1975). La technologie de l'extraction du jus de bananes et sa vinification. Thèse de doctorat. Faculté des Sciences Agronomiques de l'Etat à GEMBLOUX, Belgique.

Muriro, P. A. (2017). Crude Catalyst and Steam Distillation Into Document Control :, 1-19. 
Newilah, G. N., Tomekpe, B. K., Fokou, B. E., \& Etoa, B. F.-X. (2009). Physicochemical Changes during Ripening of Bananas Grown in Cameroon. Fresh Produce 3.1, 3(1), 64-70. Retrieved from http://www.globalsciencebooks.info/Online/GSBOnline/images/0906/FP_3(1)/FP_3(1)64-70o.pdf

Picki-reix, B. A. T. W., \& Ryburgh, G. (1986). ejects of yeast assimilable nitrogen ontwo model strains, 92, 568-571.

Raikar, R. V. (2012). Enhanced production of Ethanol from grape waste. International Journal of Environmental Sciences, 3(2), 776-783. https://doi.org/10.6088/ijes.2012030132004

Rwanda Standard Board. (2017). Uburyo buboneye bwo gukora inzoga z'ibitoki na Divayi zifatiye kubimera, (Ukwakira), 1-99.

Sablayrolles, J. M., Dubois, C., Manginot, C., Roustan, J. L., \& Barre, P. (1996). Effectiveness of combined ammoniacal nitrogen and oxygen additions for completion of sluggish and stuck wine fermentations. Journal of Fermentation and Bioengineering, 82(4), 377-381. https://doi.org/10.1016/0922-338X(96)89154-9

Serpen, J. Y. (2012). Comparison of Sugar Content in Bottled $100 \%$ Fruit Juice versus Extracted Juice of Fresh Fruit. Food and Nutrition Science, 3(November), 1509-1513. https://doi.org/10.4236/fns.2012.311196

Shale, K., Mukamugema, J., Lues, R. J., \& Venter, P. (2014). Possible microbial and biochemical contaminants of an indigenous banana beer' Urwagwa': A mini review, 8(July), 376-389. https://doi.org/10.5897/AJFS12.134

Sigmon, K. (1993). BREWING MICROBIOLOGY Third Edition. (G.lain Campbell; Priest; Fergus, Ed.) (Third edit). Kluwer Academic/Plenum Publishers New York in 2003. https://doi.org/10.1007/978-1-4419-9250-

Th.Munyanganizi, R. C. (1974). Extraction du Jus de banane. Industries Alimentaires et Agricoles.

Jiranek, V., Langridge, P., \& Henschke, P. A. (1993). Amino Acid and Ammonium Utilization by Saccharomyces cerevisiae Wine Yeasts From a Chemically Defined Medium. Copyright () 1995 by the American Society for Enology and Viticulture. All Rights Reserved., 46(1), 79-85.

Wilson, P. (2012). Microbial and Biochemical Changes Occurring During Production of Traditional Rwandese Banana Beer "Urwagwa." Fermentation Technology, 01(03), 1-4. https://doi.org/10.4172/2167-7972.1000104

\section{Copyrights}

Copyright for this article is retained by the author(s), with first publication rights granted to the journal.

This is an open-access article distributed under the terms and conditions of the Creative Commons Attribution license (http://creativecommons.org/licenses/by/4.0/). 